\title{
Analysis of Settlements along Abandoned Railway Tracks in Majalaya Subdistrict, Bandung Regency, Indonesia
}

\author{
Septi Sri Rahmawati, Sudrajat, Sri Rum Giyarsih * \\ Faculty of Geography, Universitas Gadjah Mada, Indonesia \\ *) Corresponding Author (e-mail: srirum@ugm.ac.id)
}

Received: 14 May 2020 / Accepted: 24 June 2020 / Published: 07 July 2020

\begin{abstract}
Settlements in urban areas expand as the population grows and are influenced by growth centres. This research was designed to identify the quality of informal settlements along abandoned railwaytracks in the Majalaya District, an industrial centre in Bandung Regency, Jawa Barat Province, Indonesia. A quantitative method was employed, with proportional random sampling and the use of both primary and secondary data. The primary data referred to the conditions of the slum areas, while the secondary data were images, Regional Spatial Planning (RTRW) documents and RTRW maps. The quantitative analysis employed scoring through slum settlement assessment indicators, while spatial analysis was supported by regional data. The results from the research show that although housing construction quality varies, most settlements are illegal and prone to flooding, fire, and contagious diseases. The research should be beneficial for the government in promoting and implementing slum eradication programmes in urban areas.
\end{abstract}

Keywords: Housing Quality; Slum; Informal Settlement; Abandoned Railroad Tracks, Majalaya District

\section{Introduction}

The rampant growth of slums creates a severe problem that needs to be carefully addressed, particularly in urban areas in developing countries (Satterthwaite, 2016; Amini, 2016; Ezeh et al., 2017). Outdated rules and regulations are reflections of poor urban governance, and have been reported to be the root of the rise in slum housing (Chiodelli \& Moroni, 2014). One-third of city populations in the world live in slums, posing a major challenge for urban planning and policy (Patel et al., 2014). On the other hand, for the first time in human history, more people are living in cities than in rural areas (Mahabir et al., 2016).

Slums are often characterised by lowincome communities, poor quality housing, and limited essential services and facilities (Tanni et al., 2014). In addition to insufficient access to clean water, trenches and water channels are inevitably used for waste disposal. Even though such conditions are inhumane for slum dwellers (Das et al., 2017), their low incomes force them to remain in such areas in order to meet their housing needs (Vasudevan, 2015). Supriatna \& van der Molen (2014) confirm that slums are urban residential villages consisting of dense and spontaneously growing environments in the centres or outskirts of cities. Generally, they appear on illegal land with no clear ownership, and with a lack of infrastructure and essential services, such as sewerage, clean water, and access roads. In the long run, slums becomes a threat to urban development, not only locally, but also at the regional and national levels (Patel, 2012), which calls for effective and inclusive city management policy (Abubakar et al., 2019).

Housing and settlement quality assessments are vital, especially in the case of slum management and upgrading. With 
appropriate housing planning and design, equitable and sustainable development can be achieved (Adegum, 2018). Settlement quality enhancement is aimed at economic protection, although other aspects are sometimes overlooked (Corburn \& Sverdlik, 2017). In residential areas, inclusive development is necessary, as such areas are often inhabited by economically disadvantaged populations who have problems in meeting housing demands (Rachmawati et al., 2017).

In several cities around the world, settlement improvement has drawn criticism because distances housing from sources of livelihood (Hunter \& Posel, 2012). Largescale evictions in Asian, African and South American cities have been reported to pose a new problem; that is, new slums with even poorer quality and a wider inequality gap (Ezeh et al., 2017). The failure to improve slums will lead to the expansion and formation of new slums (Lombard, 2016), mostly because slum management often ignores social, economic, environmental and institutional aspects (Sunarti et al., 2019). A comprehensive analysis can provide a complete picture of slum conditions (Mukeku, 2018).

Settlements, as the most extensive spatial utilisation, develop in line with population growth. The development of residential complexes creates unique spatial patterns and structures in cities and urban areas (Bintarto, 1983). Population growth also poses various problems in urban areas, such as slums (Nassar \& Elsayed (2018). Holmes and Argent (2016) suggest that interactions between regions and growth centres through socioeconomic development and policy also have a significant influence on land-use conversion to settlements. Hidayati et al. (2018) found that most landuse change in growth centres in urban areas involved intensive construction on built-up land, proving that urban areas are dynamic and can continue to adapt to the sprawl of residential buildings.

Growing population size can increase the need for habitable land. The mushrooming construction of housing tends to encourage land conversion, causing people to seek and choose places to reside (Rahmawati, 2019). However, limited land resources force them to live in illegal areas, such as abandoned railroads, leading to the rise of informal settlements. These are usually squalid and illegal tenements that emerge without government approval (Han et al., 2017), although slum dwellers are pushing for more established legal ownership rights, which many governments, however, are unwilling to grant (Fox, 2014).

The Ministry of Public Works and Housing (2019) has identified 18 areas of slum dwellings in Majalaya District, three of which are located along abandoned railroad tracks. Majalaya has experienced an increase in population, which is a driving force in the emergence of slums and overcrowded residential areas (Rahmawati, 2020). Moreover, its designation as an industrial development area in Bandung Regency could encourage population growth and consequently the conversion of open space into settlements. The population growth rate of Majalaya District is presented in Table 1.

Table 1. Rate of Population and Household Growth in Majalaya District

\begin{tabular}{cccc}
\hline No. & Year & Population Size & Number of Households \\
\hline 1. & 2012 & 150,643 & 42,717 \\
2. & 2013 & 151,684 & 42,188 \\
3. & 2014 & 159,216 & 54,004 \\
4. & 2015 & 162,530 & 55,096 \\
5. & 2016 & 165,621 & 57,346 \\
\hline \multicolumn{3}{c}{ Source: Processed from BPS Kabupaten Bandung, 2013-2017 }
\end{tabular}


The rate of population growth and the number of households in Majalaya District have continued to increase. Over a five year period (2012-2016), the population size increased by 14,978 people, or around $10 \%$. During the same period, the number of households rose by $34 \%$, with the addition of 14,629 households. Population growth in the study area is very high compared to the national level, which, based on BPS 2020, in the same period was $5.4 \%$. This shows that population growth in the research location is over twice the national rate.

The Ministry of Public Works and Housing (2019) states that living in a dwelling with a proper environment is a basic right of every citizen, which the government must guarantee. Efforts to increase the habitability of slums can improve housing quality, community welfare, and regional development, and these must be carefully considered and planned to provide the best options for dealing with urban and rural slums. Settlement quality in this study is based on environmental quality, such as slum levels, land legality, building resilience, and analysis of regional considerations.

Settlements along abandoned railroad tracks in Majalaya Subdistrict are characterised by their high density linear nature. The location has one narrow road; when a vehicle passes, normal life stops and people have to move various objects covering the road. In addition, low income people cover the fronts of their houses with plastic to avoid water splashing in when it rains. Residents have also raised parts of their houses because the abandoned railroad track land was flat and lower than other areas, which can lead to the settlement being flooded when there is heavy rainfall. A depiction of the conditions can be seen in Figure 1.

Majalaya has a unique urban setting, dominated by agriculture and textile industries. According to the Regional Spatial Plan of Bandung Regency for 2016-2027, as stipulated in Regional Regulation No. 27 of 2016, Majalaya has been selected as the centre for the development of the textile industry and is consequently known as the Majalaya Development Area (MDA). The MDA comprises the Majalaya, Ciparay, Solokanjeruk, Pacet, Kertasari, Paseh, and Ibun districts and functions as the centre of the textile and service/trade industries, with some residential and agricultural areas. Figure 1 shows Majalaya at the centre of the MDA; therefore, land use in the region will continue to change, with farms becoming residential areas, and a rapid growth in building because of its role as the central district for the surrounding regions. The growth centre will continue to change according to regional development.

As stated in Act No. 23 of 2007 on railways, any establishment of dwellings along railroad tracks is against the law. Based on this provision, settlements on land abutting railroad tracks in Indonesia, including Majalaya, are illegal. Consequently, sustainable and fair eradication of slums is encouraged. Based on the above discussion, it is vital to conduct studies of settlement quality in Majalaya District.

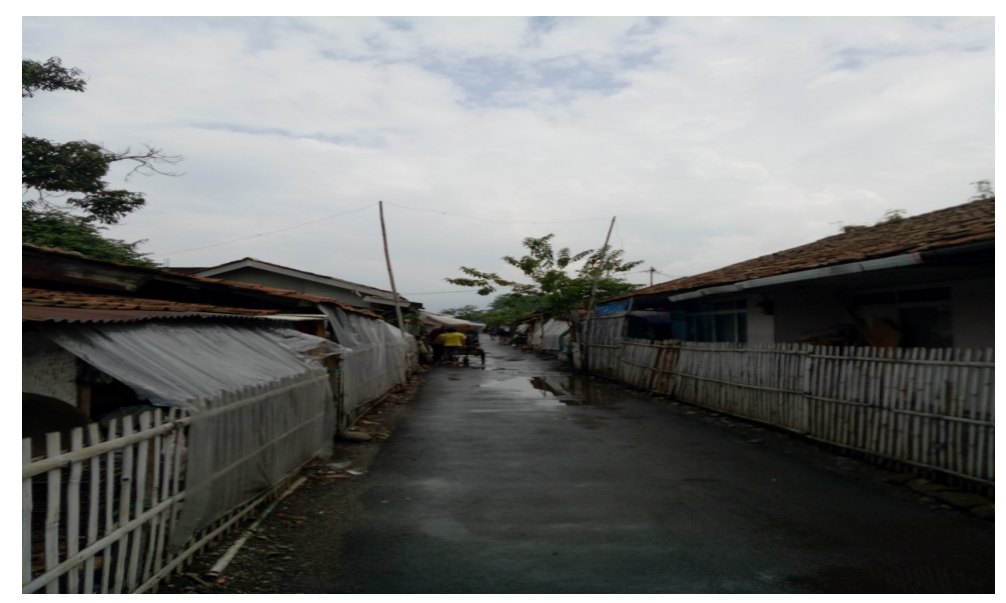

Figure 1. Image of the Conditions of the Research Location 
This research intends to identify the characteristics and analyse the quality of settlements along abandoned railroad tracks in Majalaya District, Bandung Regency. This quality assessment will provide insight into the characteristics of slums near the railroad tracks and become a reference for stakeholders in eradicating slums in sustainable and equitable ways.

\section{Research Method}

This quantitative research employed a series of survey methods, namely observation, questionnaire-guided or structured interviews, and documentation studies. After gathering both primary and secondary data, a qualitative descriptive technique with a spatial approach was used and analysed. The quantitative analysis involved scoring of the primary data, such as the condition of the slum environment and the legality of land ownership. In addition, overlay analysis was conducted after mapping the primary data, which uses several other data sources to sharpen the analysis of the region and building density. The primary data were related to the condition of the slum area, and the secondary data comprised image data and Regional Spatial Planning (RTRW) documents and maps. Samples were collected from 111 slum dwelling points along old railroad tracks in Majalaya District using proportional random sampling. A map of the research location is presented in Figure 2.

The research covered three villages, namely Padaulun, Padamulya and Majasetra, which are consistent with the data on slum distribution obtained from the Ministry of Public Works and Housing (PUPR, 2019). These villages were selected based on their major role as the centre of the textile industry in Bandung Regency, thus putting them at risk of uncontrolled population growth and densely occupied uninhabitable areas, such as abandoned railroad tracks.

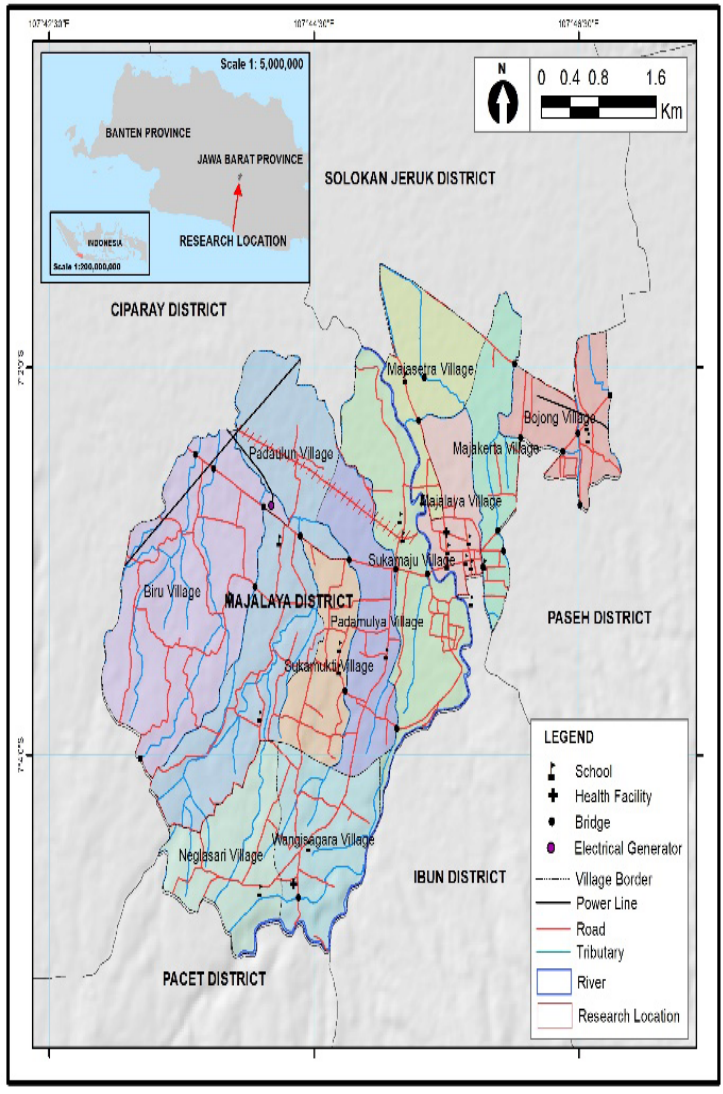

Sources: INA Geoportal (2019) and Album of Regional Spatial Plan Maps for Bandung Regency (2016)

Figure 2. Administrative Map of the Research Area 
Table 2. Measurement Aspects and Criteria of Settlement Quality

Aspect Criteria

A. Identification of Settlement Quality (1) Fair 71-95; (2) Poor 45-70; (3) Very Poor 19-44; (4) Non-Slum Dwellings $<19$

1. Housing Condition

a. Irregularity

b. Building Density

c. Substandard Housing

2. Local Access Roads

a. Reachability of Service

b. Road Surface Quality

3. Drinking Water Provision

a. Inadequate Access to Safe Drinking Water

b. Unmet Drinking Water Demand

4. Environmental Drainage

a. Inability to Drain Runoff

b. Unavailable Drainage System

c. Disconnected from Urban Drainage System

d. Poorly Maintained Drainage

e. Structural Quality of Drainage

5. Wastewater Management

a. Technically Substandard Wastewater Management System

b. Technically Substandard Wastewater Treatment Infrastructure and Facilities

6. Waste Management

a. Technically Substandard Waste Treatment Infrastructure and Facilities

b. Technically Substandard Waste Management System

c. Poorly Maintained Waste Management Infrastructure and Facilities

7. Fire Protection

a. Unavailable Fire Protection Infrastructure

b. Unavailable Fire Protection Facilities

B. Identification of the Legal Status of Land (+) Legal; (-) Illegal

Legal Status of Land

a. Security of Land Tenure

b. Compliance with Spatial Plan

C. Structural Endurance of Housing (1) Low 2-3; (2) Medium 4-6; (3) High 7-8

1. Location Hazard Level

2. Permanency of Structure Quality of Construction

D. Identification of Regional Determinants (1) High 11-15; (2) Medium 6-11; (3) Low 1-5

Other Considerations

a. Strategic Value of the Area

b. Population

c. Social, Economic and Cultural Conditions

Sources: Regulation of Ministry of Public Works and Housing No. 02/PRT/M/2016, UH-HABITAT (2010), BPS (2018), and Smit et al. (2017)

The settlement study refers to the Regulation of the Minister of Public Works and Housing No. 02/PRT/M/2016, UNHABITAT (United Nations Human Settlements Programme, 2010), BPS (2018), and Smit et al. (2017). Each indicator was assessed during the survey, and the parameters were given weight values of 5 (76\%-100\% conformity with the actual parameter), $3(51 \%-75 \%)$, and 1 (25\%$50 \%)$ and then added together to determine the total value of the settlement quality. The assessment of settlement quality is shown in Table 2.

\section{Results and Discussion \\ 3.1 Settlement Quality}

Settlement quality was identified from the primary data using indicators derived from the Regulation of the Minister of Public Works and Housing No. 02/PRT/M/2016, with the building quality criteria modified according to the indicators of settlement quality used in the 
National Socioeconomic Survey (BPS, 2018). inactive railroad tracks and is the same as the The indicators in question are as follows: (1) building irregularities; (2) local access roads; (3) availability of clean and drinking water; (4) environmental drainage; (5) wastewater management; (6) waste management; and (7) fire protection. The results of the settlement quality assessment are presented in Table 3.

Based on Table 3, the residential buildings along the abandoned railroad tracks in the district were observed to be $97 \%$ regular and $3 \%$ irregular. High building regularity is associated with the fact the area is close to

settlement patterns and regularity formed on other types of tracks, namely a linear pattern of small houses with an average width of $7 \mathrm{~m}$, varying lengths, and with the front of the house facing the tracks. However, building density reached $98 \%$, meaning that the slums were overcrowded. The field observations even showed that there was no distance between the buildings in certain areas. In addition, $55 \%$ of the buildings were permanent. The building conditions are presented in Figure 3.

Table 3. Settlement Quality

\begin{tabular}{|c|c|c|c|c|c|}
\hline No. & Indicator & Actual Parameters & Definitions & Scores & Total \\
\hline \multirow[t]{3}{*}{1.} & \multirow[t]{3}{*}{ Irregularity } & a. Irregularity & $97 \%$ of regular housing units & 1 & \multirow{3}{*}{9} \\
\hline & & b. Building Density & $98 \%$ very dense areas & 5 & \\
\hline & & c. Housing Quality & $55 \%$ permanent housing units & 3 & \\
\hline \multirow[t]{2}{*}{2.} & \multirow[t]{2}{*}{$\begin{array}{l}\text { Local } \\
\text { Roads }\end{array}$} & a. Reachability of Services & $\begin{array}{l}98 \% \text { access to roads with widths of } 1.8 \text { - } \\
2.5 \mathrm{~m}\end{array}$ & 1 & \multirow{2}{*}{4} \\
\hline & & b. Road Surface Quality & $58 \%$ poor quality roads & 3 & \\
\hline \multirow[t]{2}{*}{3.} & \multirow[t]{2}{*}{$\begin{array}{l}\text { Clean Drinking } \\
\text { Water }\end{array}$} & a. Safe Drinking Water Supply & $18 \%$ no access to safe drinking water & 1 & \multirow{2}{*}{2} \\
\hline & & $\begin{array}{l}\text { b. Unmet Demand for Drinking } \\
\text { Water }\end{array}$ & $100 \%$ met demand & 1 & \\
\hline \multirow[t]{5}{*}{4.} & \multirow[t]{5}{*}{$\begin{array}{l}\text { Environmental } \\
\text { Drainage }\end{array}$} & a. Ability to Drain Runoff & $\begin{array}{l}66 \% \text { inundated area }(>30 \mathrm{~cm} \text { deep, for } \\
>2 \text { hours, }>\text { twice per year })\end{array}$ & 3 & \multirow{5}{*}{21} \\
\hline & & b. Drainage Availability & $89 \%$ with no drainage system & 5 & \\
\hline & & c. Integration with Urban Drainage & $\begin{array}{l}40 \% \text { with no connection to urban } \\
\text { drainage }\end{array}$ & 3 & \\
\hline & & d. Drainage Maintenance & $100 \%$ poorly maintained drainage & 5 & \\
\hline & & e. Structural Quality of Drainage & $100 \%$ poorly constructed drainage & 5 & \\
\hline \multirow[t]{2}{*}{5.} & \multirow[t]{2}{*}{$\begin{array}{l}\text { W a s t e w a t e r } \\
\text { Management }\end{array}$} & a. Wastewater Management & $100 \%$ unavailable & 5 & \multirow{2}{*}{10} \\
\hline & & $\begin{array}{l}\text { b. Wastewater Management } \\
\text { Infrastructure and Facilities }\end{array}$ & $\begin{array}{l}100 \% \text { unavailability of wastewater } \\
\text { infrastructure and facilities }\end{array}$ & 5 & \\
\hline \multirow[t]{3}{*}{6.} & \multirow[t]{3}{*}{$\begin{array}{l}\text { W a s t e } \\
\text { Management }\end{array}$} & $\begin{array}{l}\text { a. Waste Infrastructure and } \\
\text { Facilities }\end{array}$ & $\begin{array}{l}67 \% \text { unavailability of waste } \\
\text { infrastructure and facilities }\end{array}$ & 3 & \multirow{3}{*}{7} \\
\hline & & b. Waste Management System & $98 \%$ managed & 1 & \\
\hline & & $\begin{array}{l}\text { c. Maintenance of Infrastructure } \\
\text { and Facilities }\end{array}$ & $\begin{array}{l}67 \% \quad \text { unavailability of } \quad \text { waste } \\
\text { infrastructure and facilities }\end{array}$ & 3 & \\
\hline \multirow[t]{3}{*}{7.} & Fire Protection & $\begin{array}{l}\text { a. Availability of Fire Protection } \\
\text { Infrastructure }\end{array}$ & $100 \%$ unavailable & 5 & \multirow{2}{*}{10} \\
\hline & & $\begin{array}{l}\text { b. Availability of Fire Protection } \\
\text { Facilities }\end{array}$ & $100 \%$ unavailable & 5 & \\
\hline & & & Total & & 63 \\
\hline
\end{tabular}




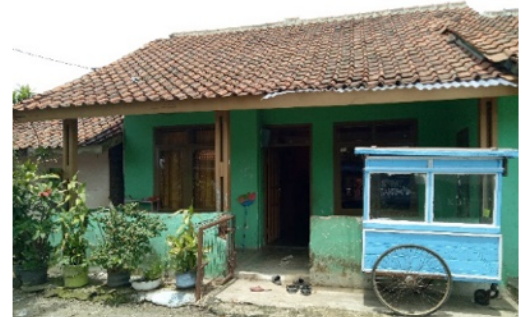

(a)

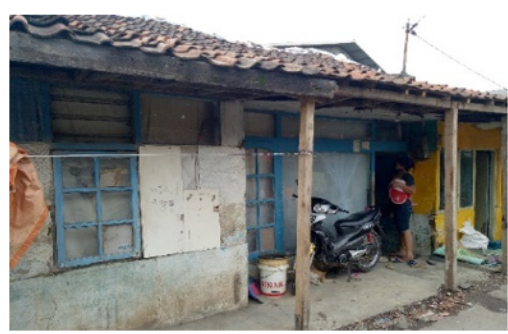

(b)

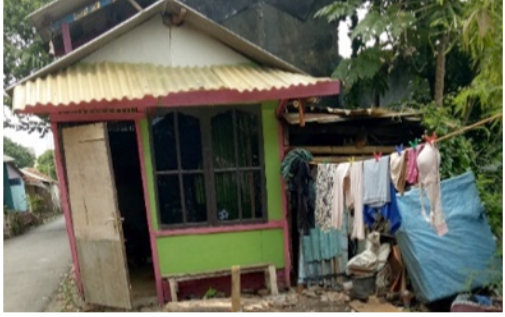

(c)

Figure 3. Housing Conditions in the Research Area: (a) Permanent; (b) Semi-permanent; (c) Non-permanent

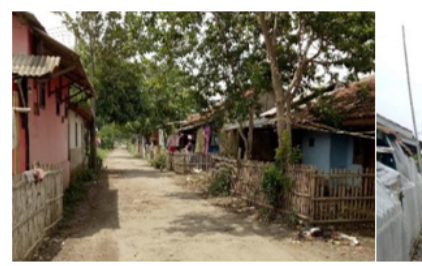

(a)

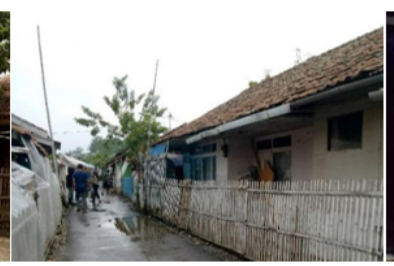

(b)

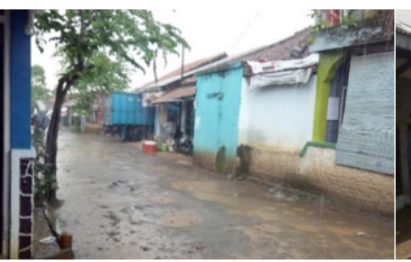

(c)

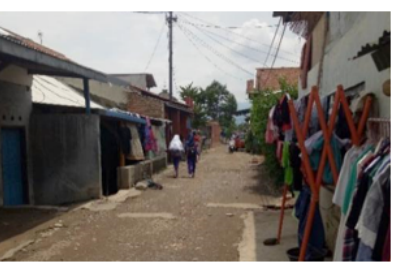

(d)

Figure 4. Conditions of Local Access Roads: (a) an asphalt road with potholes in Padaulun Village; (b) a narrow road in Padamulya Village; (c) a dirt road with puddles and mud after rain in Sukamaju Village; (d) a damaged road in Sukamaju Village

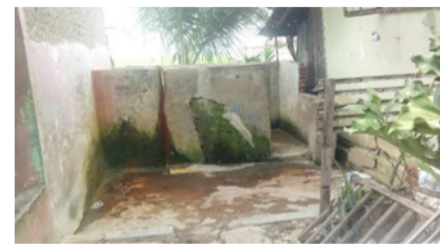

(a)

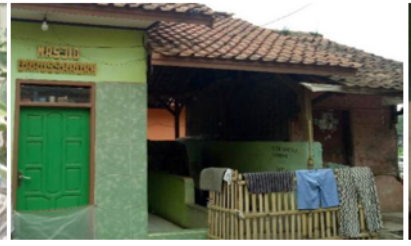

(b)

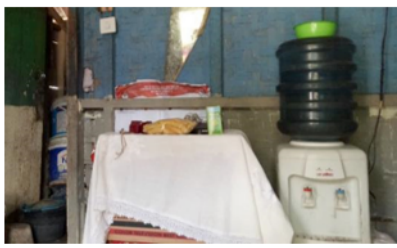

(c)

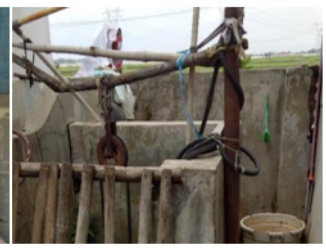

(d)

Figure 5. Water Resources in the Research Area: (a) Communal clean water source; (b) Water in the mosque as an alternative to fulfil water needs; (c) Water refill; (d) Well water

The slums in the study area comprised regular buildings with a very high density. In contrast, Setiawan et al. (2017) found that slums at an abandoned mine had moderate irregularity and density. Location is a factor in building regularity and density. The former mining site is spread over a wider area, so building density is moderate. On the other hand, the land alongside the inactive railroad tracks is narrow, meaning the settlements have a higher building density.

The second indicator of settlement quality is local access roads, which, according to Act No. 38 of 2004, have the following characteristics: (1) roads used for close-distance travel and (2) those used by vehicles at low average speeds. On roads less than 5 meters wide, vehicles move at a speed of less than $10 \mathrm{~km} / \mathrm{h}$. Table 3 shows that the reachability of the local access roads was very high. Local roads with an average width of two meters reached up to $98 \%$ of the houses. This condition is typical of settlements formed alongside abandoned railroad tracks because the former transportation line was transformed into a local single-track road with independent funding and financial aid. Pictures of the local access roads can be seen in Figure 4.

In $58 \%$ of the study area, the road surfaces were found to be of poor quality. In general, the local access roads were not paved with 
concrete or asphalt because a land dispute between the community and PT. KAI (the Indonesian Railway Company) has hampered any attempts at road repair. Nevertheless, certain parts of the slum areas had good quality roads, while others were traversed by gravel roads. Such roads are often inundated during the rainy season, and as most of the potholes are not visible due to the resultant puddles, the risk of motorcycle accidents on these roads is high. In the slum areas observed, motorcycles are the most commonly owned means of transportation.

The third indicator, drinking water supply, includes the supply of safe drinking water and the fulfillment of daily water needs. In general, $82 \%$ of the community already had access to safe drinking water, while the remaining $18 \%$ drew water from wells. Unfortunately, the well water was yellow, had a metallic odour, and tasted somewhat bitter, which are signs of suspected contamination from the surrounding textile factories. Sources of drinking water at the study site are presented in Figure 5.

The settlements along the abandoned railroad tracks represent one of the most densely populated areas in Majalaya District. The area that is situated in the core zone of the industrial estate encourages residents to occupy the location to earn their livelihoods. Its southeastern part is the most densely populated area compared to other abandoned railroad track settlements, as it is the closest location to the industrial estate, has more complete education facilities, and is also closer to the activity centre in Majalaya District. In addition, in general the research location has an elongated pattern, in accordance with the existence of land owned by PT. KAI, which was originally used as a link between Majalaya District and other regions in Bandung Regency. An image of the research location is shown in Figure 6.

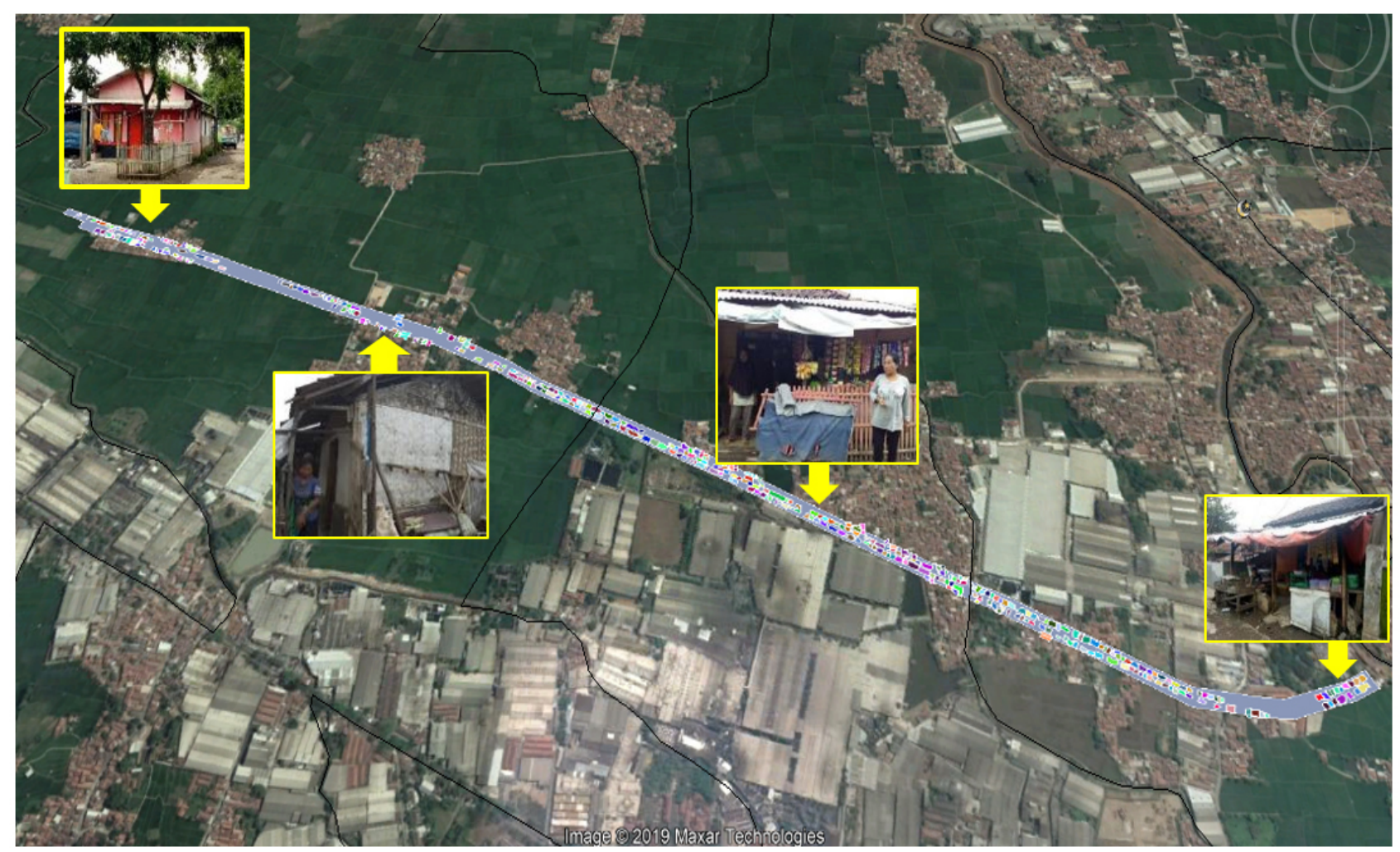

Source: Google Earth Imagery V 6.2.2.6613 (2019)

Figure 6. Overview of Research Location 


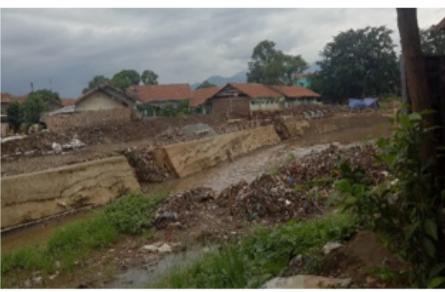

(a)

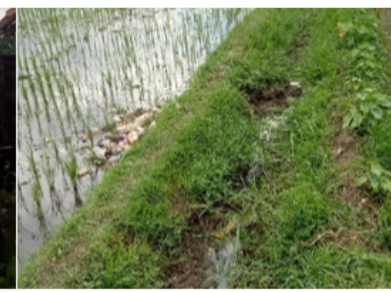

(b)

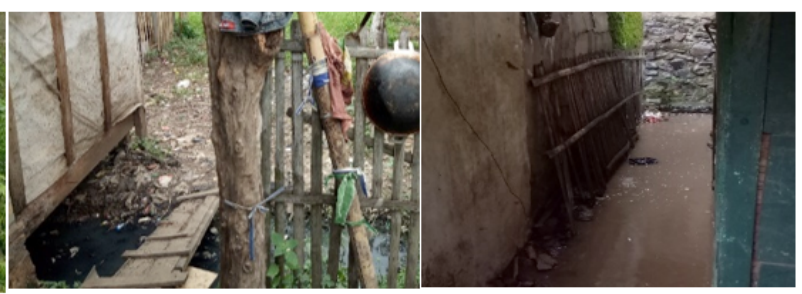

(c)

(d)

Figure 7. Components of the Drainage System in the Research Area: (a) Citarum, the estuary of the urban drainage system; (b) irrigation channels used to dispose of domestic waste; (c) stalled drainage channels; (d) flooding caused by lack of drainage.

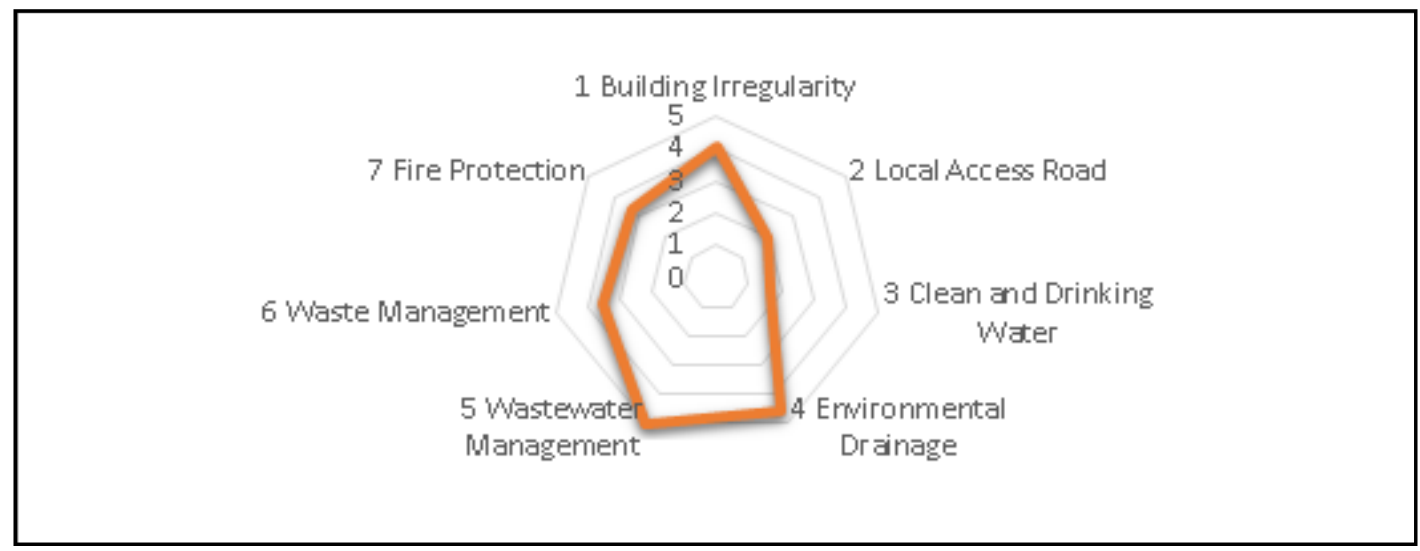

Figure 8. Diagram of the Settlement Conditions for Each Research Indicator

The fourth indicator, drainage conditions, was assessed from the ability of the environment to drain runoff, availability, connection to urban drainage, maintenance, and structural quality. At least twice a year, around two thirds of the buildings were inundated up to $30 \mathrm{~cm}$ for more than two hours. Good drainage was found in $11 \%$ of the area, while the other $89 \%$ had very limited drainage.

The Ministry of Public Works and Housing (2012) defines drainage as infrastructure that functions to channel excess water from an area to water bodies, and urban drainage as an infrastructure in urban areas that functions to manage or control surface water so that it does not harm the community. Based on these definitions, $40 \%$ of the drainage in the study area was not connected to the urban drainage system. In addition, its maintenance and structural quality were categorically poor. All households disposed of their domestic waste into trenches that transport water to nearby paddy fields, which consequently contaminate rice fields with garbage and human excrement. In other words, these water channels have been turned into a giant septic tank. Pictures of the drainage channels are presented in Figure 7.

The fifth indicator, wastewater management systems, consists of wastewater management components, facilities and infrastructure. The research revealed that the study area did not have a wastewater management system (facilities or infrastructure); therefore, all domestic waste was discarded directly into trenches or gutters connected to the surrounding rice fields. 


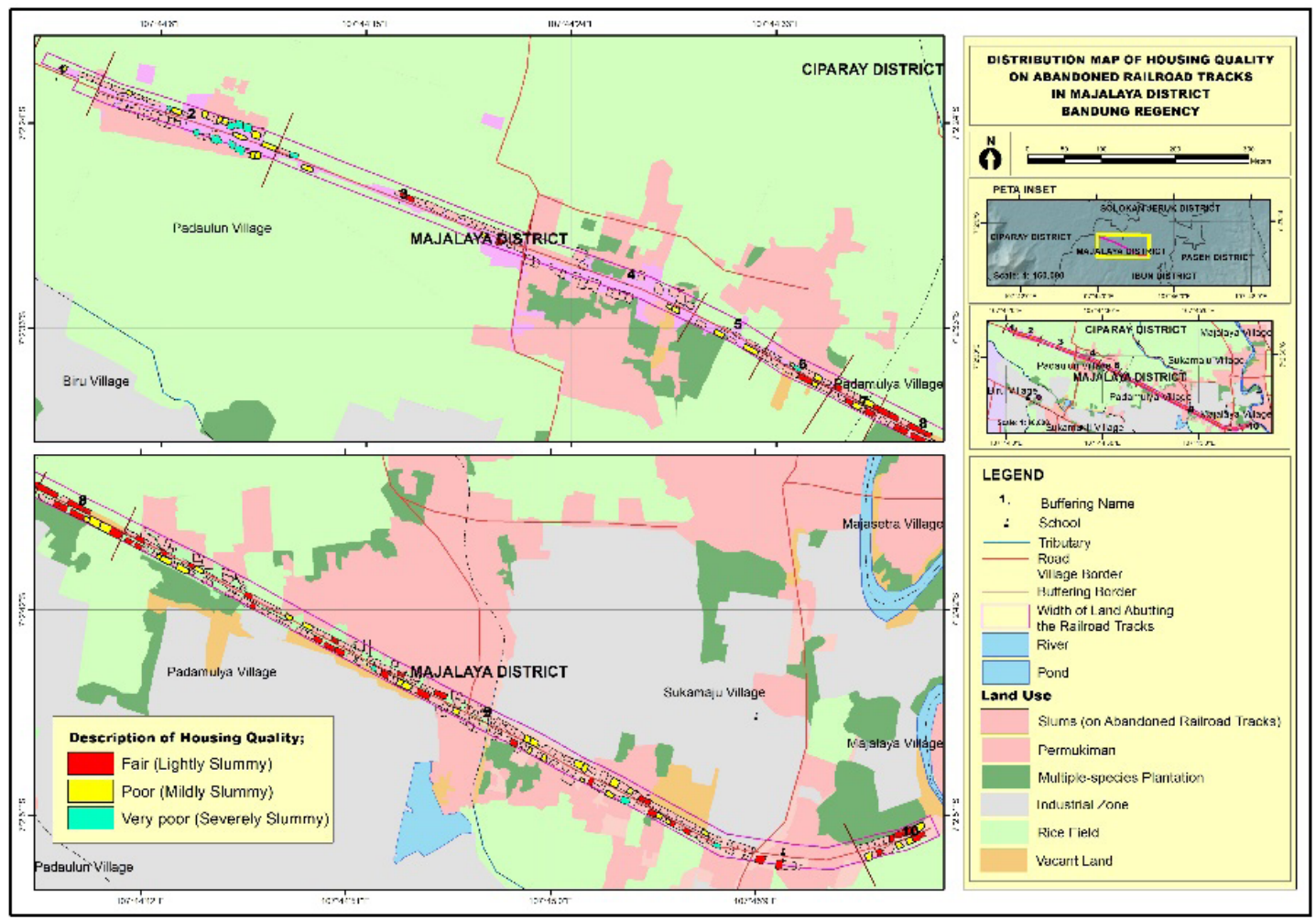

Sources: (1) Interpretation of Google Earth Imagery V 6.2.2.6613 (2019); (2) SHP Data for Bandung Regency by the Geospatial Information Agency (2019); and (3) Album of Regional Spatial Plan Maps for Bandung Regency (2016);

Data Analysis (2020).

Figure 9. Distribution of Settlement Quality

Table 4. Distribution of Settlement Quality

\begin{tabular}{clll}
\hline No. & \multicolumn{1}{c}{ Settlement Quality } & Total Number & Percentage \\
\hline 1. & Non-slum Dwellings & 0.0 & 0.0 \\
2. & Fair (Slightly Slummy) & 8.0 & 7.2 \\
3. & Poor (Mildly Slummy) & 56.0 & 50.5 \\
4. & Very Poor (Severely Slummy) & 47.0 & 42.3 \\
\hline & Total & 111 & 100.0 \\
\hline
\end{tabular}

Finally, fire protection was determined from the availability of supporting facilities and infrastructure. The research location was not equipped with fire protection infrastructure. Therefore, this indicator had low scores, especially in locations with low water availability and roads that could not be accessed by fire trucks. In the case of fire, the area was at an extremely high risk of losses. The scores of all the indicators are presented in Figure 8, while the distribution of settlement quality is depicted in Figure 9.
After calculating the indicators above, the distribution of housing quality was established. Table 4 shows that half of the slum dwellings (50.5\%) were squalid, and none was categorised as a non-slum dwelling. Severely and slightly slummy housing was found in $42.3 \%$ and $7.2 \%$ of the total area respectively. This condition is attributable to the low scores of several indicators, namely fire protection, waste management, drainage, and the physical quality of the buildings. The legal status of the land also contributes to the low willingness 
of slum dwellers to improve their housing quality. Moreover, no middle ground has been established between PT. KAI, as the rightful land title holder, and the community or local government.

The results show that most houses in the slums were mildly slummy or in poor conditions. This finding is consistent with Setiawan et al. (2017) and Amalia (2018). According to Amalia (2018), slum dwellings in Kampung Sapiria, Lembo Sub-district, which has a strategic location in Makassar City, were mostly in poor condition. Adyani et al. (2018) also found that poor quality dwellings had sprung up on the banks of Winongo River, Yogyakarta City. Different results have been obtained for regions with the status of 'city' in Indonesia. Wiarni et al. (2018) describe the residential area in Kotamobagu Timur District, one of the cities in Sulawesi Utara Province, as a poor slum settlement. Meanwhile, Wihandanto et al. (2017) classified the settlement quality of Kampung Braga, Bandung City, as severely slummy or very poor. In conclusion, a more densely populated area is inclined to have poorer housing quality.

\subsection{Legal Status of Land}

The legal ownership of land and property is one of the main problems for slum households (Ezeh et al., 2017). The clear legal status of land is evidenced by the legal strength of the land tenure certificate, while suitability of land use refers to the 2016 Regional Spatial Plan map of Bandung Regency. Based on these documents, the legal status of land in the slum settlements observed is presented in Table 5 .

Table 5. Legal Status of the Land Occupied

\begin{tabular}{cccc}
\hline No. & $\begin{array}{c}\text { Legal } \\
\text { Status }\end{array}$ & $\begin{array}{c}\text { Total } \\
\text { Number }\end{array}$ & Percentage \\
\hline 1. & Legal & 3.0 & 2.7 \\
2. & Illegal & 108.0 & 97.3 \\
\hline & Total & 111 & 100.0 \\
\hline
\end{tabular}

Table 5 shows that $97.3 \%$ of the slum housing was built illegally without legitimate agreement with the land's rightful owners, while the other $2.7 \%$ occupied land legally. Valid legal status exists when residents use the land alongside the abandoned railroad tracks as their front yard and build their houses behind this. Therefore, in cases of eviction, they can stay in legally occupied land. This situation is similar to that of slum settlements formed on some riverbanks in Kampung Sapiria, Makassar City, in which only $5 \%$ of the residents built their houses on land with a clear legal status (Amalia, 2018). In other words, housing quality is generally affected by the legal status of the land occupied.

\subsection{Housing Structural Endurance}

Structural endurance refers to factors concerning location safety and house structure (UN HABITAT, 2010; BPS, 2018). The structural endurance of the housing in the study area is summarised in Table 6.

Table 6. Housing Structural Endurance

\begin{tabular}{cccc}
\hline No. & $\begin{array}{c}\text { Structural } \\
\text { Endurance }\end{array}$ & $\begin{array}{c}\text { Total } \\
\text { Number }\end{array}$ & Percentage \\
\hline 1. & High & 3.0 & 2.7 \\
2. & Medium & 34.0 & 30.6 \\
3. & Low & 74.0 & 66.7 \\
\hline & Total & 111 & 100.0 \\
\hline
\end{tabular}

Table 6 shows that most of the housing $(66.7 \%)$ was of low endurance, with $30.6 \%$ having medium endurance and $2.7 \%$ high endurance. Factors resulting in low endurance included:

(1) Flood-prone areas due to lack of drainage. Almost all the trenches in the area are closed to support house structures; hence, during rain events, unaccommodated rainwater tends to overflow from these water channels. In addition, densely populated areas increase the risk of catastrophic fires and the rapid spread of disease.

(2) Core industrial zone location. This region is exposed to serious water and air 
pollution. Moreover, since the trenches are used as toilets and/or septic tanks, any overflowing water enters the houses and tends to carry not only household waste but also human excrement.

(3) Unprotected high-risk zones. According to the 2016 Regional Spatial Plan map of Bandung Regency, the slums sprawl in areas intended to support railroad facilities. More often than not, the residents receive information about eviction from neighbourhood officials, and sometimes even hoaxes are created by groups for various purposes.

\subsection{Regional Considerations}

The final determinant of housing quality, which can be used as a reference in policy directives, is regional considerations. These were determined according to the Regulation of the Minister of Public Works and Housing No. 02/PRT/M/2016, with the strategic value of the location, population and socioeconomic conditions factored in, as presented in Table 7.

Based on Table 6, all the slums scored as medium in terms of regional considerations. The area was found to have a strategic value as it is located in the industrial development area in Bandung Regency and is densely populated, with over 400 people per hectare. However, from a social perspective, the slum housing had a low score because most of their residents were not of a particular indigenous tribe, meaning that no specific local wisdom and culture had developed in this area. Future development of policy directives must take into account regional conditions and values of slums.

Regional considerations are highly relevant to housing quality. Because the study area is close to industrial estates, the settlements have grown rampantly, which is consistent with Holmes and Argent (2016). The transformation of land alongside abandoned railroad tracks into informal settlements increases building density, and housing quality continues to decline, becoming increasingly uninhabitable. With a very high population density, i.e., more than 400 people per hectare, housing quality is therefore likely to deteriorate.

Table 7. Regional Determinants

\begin{tabular}{cccc}
\hline No. & $\begin{array}{c}\text { Regional } \\
\text { Determinant }\end{array}$ & $\begin{array}{c}\text { Total } \\
\text { Number }\end{array}$ & Percentage \\
\hline 1. & High & 0.0 & 0.0 \\
2. & Medium & 111.0 & 100.0 \\
3. & Low & 0.0 & 0.0 \\
\hline & Total & 111 & 100.0 \\
\hline
\end{tabular}

\section{Conclusion}

Although the housing quality alongside the abandoned railroad tracks in Majalaya District varies, it is mostly poor to very poor, illegal, and comprises informal houses with low disaster resilience and moderate regional values (considerations). The low quality of the settlements is partly a result of low fire protection, lack of household waste management, limited drainage conditions, and the physical condition of the semi-permanent and non-permanent buildings. Very poor (severely slummy) dwellings are located on the border of Padamulya and Padaulun Villages, fair quality (lightly slummy) houses are scattered in the second settlement block, and poor (moderately slummy) housing is distributed evenly in the area.

Structured and planned repairs are needed to upgrade the housing quality. Improvements in environmental parameters must focus on the drainage system, building density, waste management and fire protection, which can automatically create more habitable housing. The study area has lost most of its water management systems, green open spaces, and sewage systems. Without an increase in housing quality, the closely packed buildings and lack of working drainage will contribute to the proneness to flooding, extensive catastrophic fires, and the rapid spread of infectious diseases. Another 
danger that may arise from declining housing quality in this location is floods in surrounding residential areas.

The poor condition of the settlement environment shows that the low income people who occupy this location only consider the land as a place to live without being supported by environmental awareness. The unclear legal status of the land needs to be resolved immediately to improve the quality of the settlement for better settlement arrangement in urban areas. If successfully implemented, this step could be adopted in the arrangement of illegal and informal settlements along abandoned railroad tracks in other regions in Indonesia that have similar community and regional characteristics.

\section{Acknowledgments}

This paper is part of a Master's thesis by Septi Sri Rahmawati under the supervision of Dr. Sudrajat and Prof. Dr. Sri Rum Giyarsih. The author would like to thank the Educational Fund Management Agency (LPDP) of the Ministry of Finance of the Republic of Indonesia for funding the research. Acknowledgments are also extended to the government of Majalaya District, Bandung Regency, Jawa Barat Province, for granting the research permit and to those who assisted with the research.

\section{References}

Abubakar, A., Romice, O., \& Salama, A. M. (2019). Slums and prosperity: a complex, dynamic pathway of intervention. International Journal of Architectural Research, 314-330. doi:0.1108/ ARCH-02-2019-0041

Adegum, O. B. (2018). Exploring Just Sustainability in Re-Blocking Intervention in a Johannesburg Informal Settlement. Journal of Asian and African Studies, Vol. 53(5), 782-796. doi:10.1177/0021909617725771

Adyani, E., Veronika, Sani, M., \& Sarwadi, A. (2018). Hubungan Kualitas Lingkungan Permukiman dan ingkat Kesehatan Maysarakat di Permukiman Kumuh Bantaran Sungai Winongo, Kota Yogyakarta. Prosiding Seminar Nasional Asosiasi Sekolah Perencanaan Indonesia (ASPI) 2018. Bogor: P4W LPPM., pp. 524-535.

Amalia, A. A. (2018). Karakteristik Hunian Permukiman Kumuh Kampung Sapiria Kelurahan Lembo Kota Makasar. National Academic Journal of Architecture. Volume 5, pp. 13-22.

Amini, E. (2016). An Analysis on Physical-Environmental Quality of Informal Settlements and its Role in The Vitality of Citizens, Case Study: Informal Settlement of Qom City, Sheikhabad Neighborhood. The Turkish Online Journal of Design, Art and Communication - TOJDAC, Special Edition, 2657-2662. doi:10.7456/1060NVSE/071

Badan Informasi Geospasial (BIG). (2019). Data SHP Kabupaten Bandung. Available Online: https:// tanahair.indonesia.go.id/ [10 November 2019]

Bintarto, R. (1983). Pola Kota dan Permasalahannya. Yogyakarta: Fakultas Geografi Universitas Gadjah Mada.

Badan Pusat Statistik (BPS). (2020). Statististik Indonesia 2020. Jakarta. Available Online: https://www.bps.go.id/publication/2020/04/29/e9011b3155d45d70823c141f/statistikindonesia-2020.html [21 Juny 2020]

Badan Pusat Statistik (BPS). (2018). Survey Sosial Ekonomi Nasional (Susenas) 2018. Jakarta.

BPS Kabupaten Bandung. (2017). Kecamatan Majalaya dalam Angka Tahun 2017. Available Online: https:/ / bandungkab.bps.go.id [15 December 2019]

BPS Kabupaten Bandung. (2016). Kecamatan Majalaya dalam Angka Tahun 2016. Available Online: https:// bandungkab.bps.go.id [15 December 2019] 
BPS Kabupaten Bandung. (2015). Kecamatan Majalaya dalam Angka Tahun 2015. Available Online: https:/ / bandungkab.bps.go.id [15 December 2019]

BPS Kabupaten Bandung. (2014). Kecamatan Majalaya dalam Angka Tahun 2014. Available Online: https:// bandungkab.bps.go.id [15 December 2019]

BPS Kabupaten Bandung. (2013). Kecamatan Majalaya dalam Angka Tahun 2013. Available Online: https:/ / bandungkab.bps.go.id [15 December 2019]

Chiodelli, F., \& Moroni, S. (2014). The complex nexus between informality and the law: Reconsidering unauthorised settlements in light of the concept of nomotropism. Geoforum, 51, 161-168. doi:10.1016/j.geoforum.2013.11.004.

Corburn, J., \& Sverdlik, A. (2017). Slum Upgrading and Health Equity. International Journal of Environmental Research and Public Health, 14, 342, 1-12. doi:10.3390/ijerph14040342

Das, S., Mitra, A., \& Kumar, R. (2017). Do neighbourhood facilities matter for slum housing? Evidence from Indian slum clusters. Urban Studies, Vol. 54(8), 1887-1904. doi:10.1177/0042098016634578

Ezeh, A., Oyebode, O., Satterthwaite, D., Chen, Y.-F., Ndugwa, R., Satori, J.. Lilford, R. (2017). The history, geography, and sociology of slums and the health problems of people who live in slums. Lancet, 389, 547-559. doi:10.1016/S0140-6736(16)31650-6

Fox, S. (2014). The Political economy of slums: Theory and evidence from Sub-Saharan Africa. World Development, 54, 191-203. doi:10.1016/j.worlddev.2013.08.005.

Google earth V 6.2.2.6613. (21 Juli 2019) Kecamatan Majalaya $107^{\circ} 45^{\prime}-107^{\circ} 52^{\prime} \mathrm{BT}$ dan $6^{\circ} 59^{\prime}-7^{\circ} 50^{\prime} \mathrm{LS}$, Eye alt 617 m. DigitalGlobe 2019. http:/ / www.earth.google.com [10 November 2019]

Han, Y., Song, Y., Burnette, L. B., \& Lammers, D. (2017). Spatiotemporal Analysis of the Formation of Informal Settlements in a Metropolitan Fringe; Seoul (1950-2015). Sustainability. Vol. 9, pp. $1-18$

Hidayati, I. N., Suharyadi, R., \& Danoedoro. (2018, Juli). Developing an Extraction Method of Urban Built-Up Area Based on Remote Sensing Imagery Transformation Index. Forum Geografi. Vol. XXXII (1), pp. 96-108.

Holmes, J., \& Argent, N. (2016). Rural Transitions In The Nambucca Valley: Socio-Demographic Change In A Disadvantaged Rural Locale. Rural Study. Vol 48, pp. 129-142.

Kementrian Pekerjaan Umum dan Perumahan Rakyat (PUPR). 2019. Daftar Permukiman Kumuh Kecamatan Majalaya. Retrieved September 24, 2019, from http:/ / kotaku.pu.go.id/.

Kementrian Pekerjaan Umum (PU). (2012). Tata Cara Penyusunan Rencana Induk Sistem Drainase Perkotaan. Jakarta: Direktorat Jenderal Cipta Karya.

Lombard,M.(2016).Land conflictinperi-urbanareas:Exploringtheeffectsofland reformoninformal settlement in Mexico. Urban Studies, Vol. 53(13), 2700-2720. doi:10.1177/0042098015603569

Mahabir, R., Crooks, A., Croitoru, A., \& Agouris, P. (2016). The study of slums as social and physical constructs: challenges and emerging research opportunities. Regional Studies, Regional Science, 399-419. doi:10.1080/21681376.2016.1229130

Mukeku, J. (2018). Urban Slum Morphology and Socio-economic Analogies: A Case Study of Kiberia Slum, Nairobi, Kenya. Urbanisation, 3 (1), 17-32. doi:10.1177/2455747118790581

Nassar, D. M., \& Elsayed, H. G. (2018). From Informal Settlements to Sustainable Communities. Alexandria Engineering Journal. Vol. 57, pp. 2367-2376. 
Patel, A., Crooks, A. T., \& Koizumi, N. (2012). Simulation: An agent-based modeling approach to slum formations. Journal of Artificial Societies and Social Simulation, 15, 2. Retrieved from http://jasss.soc.surrey.ac.uk/15/4/2.html. doi:10.18564/jasss.2045.

Patel, A., Koizumi, N., \& Crooks, A. (2014). Measuring slum severity in Mumbai and Kolkata: A household-based approach. Habitat International, 41, 300-306. doi:http://dx.doi. org/10.1016/j.habitatint.2013.09.002

Peraturan Daerah Nomer 27 Tahun 2016 Tentang RTRW Kabupaten Bandung. (2016).

Rachmawati, R., Budiarti, C. V., Febrita, D., \& Sulistyani, E. (2017, December). Inclusive Development through Providing Vertical Housing for Low Income Family in Yogyakarta Urban Areas. Forum Geografi, XXXI, 246-257. doi:10.23917 / forgeo.v31i2.5132

Rahmawati, S. S., Sugandi, D., Jupri, \& Nandi. (2019). Kajian Karakteristik Lahan Untuk Permukiman Di Kecamatan Padalarang Kabupaten Bandung Barat. Prosiding Seminar Nasional Geografi II.

Rahmawati, S.S. (2020). Kajian Kualitas Permukiman Masyarakat Ex-Bantaran Rel Kereta Api di Kecamatan Majalaya Kabupaten Bandung. Tesis. Fakultas Geografi UGM. Tidak dipublikasikan

Setiawan, L. A., Astuti, W., \& Rini, E. F. (2017). Tingkat Kualitas Permukiman (Studi Kasus: Permukiman Sekitar Tambang Galian C Kecamatan Weru, Kabupaten Sukoharjo). Jurnal Pembangunan Wilayah dan Perncanaan Partisipatif, 1-11. Retrieved September 26, 2019, from https://jurnal.uns.ac.id/region/article/view/15922/17166

Smit, S., Musango, J. K., Kovacic, Z., \& Brent, A. C. (2017). Conceptualising slum in an urban African context. Elsevier: Cities, 107-119.

Supriatna, A., \& van der Molen, P. (2014). Land Readjustment for Upgrading Indonesian Kampung. a Proposal South East Asia Research, 379-397.

UN-Habitat, (. N.-H. (2010). The challenge of slums. Retrieved September 20, 2019, from unhabitat. org: $\quad$ http://unhabitat.org/wp-content/uploads/2003/07/GRHS_2003_Chapter_01_ Revised_2010.pdf

Vasudevan, A. (2015). The makeshift city. Towards a global geography of squatting. Progress in Human Geography, 39, 338-359. doi:10.1177/0309132514531471.

Wiarni, S., Mononimbar, W., \& Supardjo, S. (2018). Analisis Tingkat Kekumuhan Kawasan Permukiman Di Kecamatan Kotamobagu Timur. Jurnal Spasial, 5n (1), 61-70.

Wihadanto, A., Barus, B., Achsani, N. A., \& Bratakusumah, D. S. (2017). Analisis Karakteristik dan Penilaian Tingkat Kekumuhan Kawasan Permukiman 'Kampung Braga' Kota Bandung. Journal of Regional and Rural Development Planning, 1 (2), 132-244. 